International Journal of Instruction e-ISSN: 1308-1470 • www.e-iji.net

Article submission code: 20201009094331

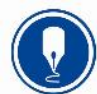

October $2021 \bullet$ Vol.14, No.4

p-ISSN: 1694-609X

pp. 713-732

Received: 09/10/2020

Revision: 18/04/2021
Accepted: 12/05/2021

OnlineFirst: 02/09/2021

\title{
Online Reading Skills as an Object of Testing in International English Exams (IELTS, TOEFL, CAE)
}

\section{Rimma Ivanova}

Linguistics University Nizhny Novgorod, Nizhny Novgorod, Russia, ivanovarim03@rambler.ru

\section{Andrey Ivanov}

Linguistics University Nizhny Novgorod, Nizhny Novgorod, Russia, ivanov_a.2425@rambler.ru

\begin{abstract}
The present article addressed the issue of university teachers' working experience in the field of class-oriented online teaching English in higher educational institutions. The central aim of this study was a detailed description of the system for assessing reading skills utilized in English proficiency tests (CAE (C1), TOEFL, IELTS), as well as a comprehensive analysis of testing results. As a part of a thorough investigation, the article detailed three major reading modes and tasks most commonly used in such tests (scan-reading, skim-reading, and in-depth reading). Besides, in order to obtain reliable conclusions about the reasonability of the test tasks, the study took into account the tests' duration, the number and types of tasks, as well as the length of reading passages proposed. The research population comprised 622 second-year students from all faculties of the National Research University "Higher School of Economics" (Nizhny Novgorod Campus, Russia) with English proficiency levels from B1 to $\mathrm{C} 1+$. All data required for the study were collected from the outcomes of international English exams (CAE (C1), TOEFL, IELTS), conducted in the form of testing in 2013, 2014, and 2015. The results of this examination showed that $97 \%$ of students involved successfully solved multiple choice tasks, 96\% demonstrated an understanding of the dependence between headings and text fragments, and 95\% succeeded in gapfilling tasks. Provided that research participants were engaged in active work on English reading comprehension improvement throughout the examination period, $95 \%$ of students have mastered their reading skills.
\end{abstract}

Keywords: e-learning, reading, online environment, strategies, language proficiency tests, testing

\section{INTRODUCTION}

The era of technological development and digitalization requires more sophistication from educational technologies and better professional competencies and skills from

Citation: Ivanova, R., \& Ivanov, A. (2021). Online reading skills as an object of testing in international English exams (IELTS, TOEFL, CAE). International Journal of Instruction, 14(4), 713732. https://doi.org/10.29333/iji.2021.14441a 
university teachers. The modern learning process is more likely to take place in an online environment. In view of this, 21 st-century education tends to be guided by the principles and technologies of e-learning. The issues of e-learning and the corresponding development of higher education are the focus of researchers all over the world, including in Russia (Axmatilloyevna et al., 2020; Bandalos, 2018; Player-Koro, 2019). Therefore, for many developing countries, and Russia as well, the central task is to train specialists who are able to compete in international labor markets on an equal footing. One of the ways to achieve this aim is the implementation of e-learning in education. It helps the teacher identify which topics are difficult for students to cope with and thereby focus on them. The increasing use of online technology allows us to use multimedia content, be involved in continuous communication and interaction, draw diagrams, take notes, complete tasks, participate in videoconferences, and many more (Demitriadou et al., 2020; Pachler et al., 2010). A newer and more portable version of elearning is mobile learning, named after portable devices that are sometimes small enough to fit in a pocket or palm (Briz-Ponce et al., 2017). The main advantages of mobile learning as modern educational technology are its versatility, individual approach to students, opportunity to be engaged in education anytime and anywhere, and the ability to maintain motivation by modifying and improving the educational process (Fojtik, 2014; Yang, 2013).

To date, many authors have analyzed the competence of those learning English as a second language through online tests. Testing as a form of examination is successfully applied both during in-class and distance learning a foreign language (Aziz \& Yusoff, 2018; Black, 2018; Giraldo, 2018; van der Linden, 2018; Zhang, 2016; Zubkov, 2020). A test was previously interpreted as "a process, which is administered to measure students' ability to perform in a specific field in a certain time limit with a specific goal." Now, this term is determined as "a qualimetric verified system of the test tasks carried out in the framework of a standardized procedure" (Hura, 2017; Matsuda, 2017; Shohamy et al., 2017; Urmston et al., 2016; Wibowo et al., 2020).

In the process of English proficiency examination, all four basic language skills are tested: listening, reading, writing, and speaking. The success of the exam is determined by the number of points scored (Kameneva et al., 2018; Purpura \& Christison, 2016; Seok \& DaCosta, 2017; Shohamy et al., 2017; Urmston et al., 2016). Many studies convincingly confirm the fact that the prosperous development of students' foreign language competence can be identified using online testing tools. What is more, online tests can also provide an opportunity to assess the level of language acquisition objectively. Initially, testing as such was designed to eliminate the subjective factor in assessing academic performance. A comprehensive analysis of test results is supposed to suggest the most effective learning strategies and increase student motivation (Craven, 2017; Rahman, 2017; Shohamy et al., 2017; Susanto et al., 2020; Tkachenko \& Bredikhina, 2019). Based on this, testing can serve as the basis for monitoring the quality of education in institutions of any type (Adesope et al., 2017; van der Linden, 2018; Zhang, 2016; Zubkov, 2020). Another important point is that the set of testing tasks meets the requirements for its quality. The main measurable characteristics of a 
test are reliability, validity, practical usability, efficiency, and differentiation of students' scores (Tkachenko \& Bredikhina, 2019; Weideman, 2019; Zumbo \& Hubley, 2016).

The defining moment for optimizing the education process is the system for assessing the quality of knowledge. Now it is implemented through a system of exams and certification procedures (Axmatilloyevna et al., 2020; Hooshyar et al., 2020). In connection with the proliferation of e-learning and the desire for independent and objective assessment of students, online testing is becoming a common form of assessing knowledge. Therefore, the evaluation of English proficiency level is carried out mainly in the form of a test.

Many researchers consider reading as an aspect of learning a foreign language to be the most important part of students' cognitive activity. It is reading online that acts as a basic structural part of e-learning and provides the perception of most of the educational material. What is more, reading is believed to contribute to the development of communication abilities (Cho \& Krashen, 2019; Grabe \& Stoller, 2019; Hedgcock \& Ferris, 2018; A. Ihata \& T. Ihata, 2017; Ulker, 2019). In view of the foregoing, the current research addresses only the Reading section in tests (Bilikozen \& Akyel, 2014; Delfi et al., 2020; Grabe \& Jiang, 2018; Pollock, 2018).

In order to read effectively, one needs to use different reading techniques for different purposes and texts. Skimming is known as reading a passage to determine a general idea of the text quickly. No less effective way to work with a text is scanning. It helps a reader swiftly find specific information in the passage (name/title, date, number). When scanning, reading comprehension occurs in the process of perception, understanding, and estimation of information difficulty. Particularly this process indicates the reader's competence level (McNamara et al., 2017). Goal-setting determines the volume, accuracy, and depth of the information extracted from the text as well as self-monitoring carried out by the student. In the meantime, reading allows one to monitor the effectiveness and correctness of his/her mental operations.

Testing reading skills is proved to be very useful because (1) it contributes to the maximally effective training of cognitive activity of a student, faced with the need to understand the content of the text and interpret it as deeply as possible; (2) different tests involve tasks of different volumes, varying in difficulty and language peculiarities; (3) reading test is the best way to examine the linguistic skills developed during elearning, which is proved by their ubiquitous use in language proficiency tests (Adesope et al., 2017; Shohamy et al., 2017).

The similarity of all exam formats is manifested, first of all, in the fact that they reveal learners' competencies. As of today, three of the most popular English proficiency tests are IELTS, CAE, TOEFL. Based on their results, individuals enrolled can receive a certificate for attesting their competence in English according to the scale of the Common European Framework of Reference for Languages (CEFR) (Bae et al., 2019). Specialized preparation for such exams is increasingly being conducted online, which increases the importance of online reading for passing the exam (Shohamy et al., 2017). The TOEFL and IELTS certificates are valid for two years, whereas the CAE has no 
expiration date. For a more comprehensive assessment of students' reading skills, the present study uses three tests - IELTS, CAE, TOEFL - as each has its unique features. IELTS and CAE examine British English, while TOEFL is designed specifically to test the knowledge of American English (Axmatilloyevna et al., 2020). Whereas the TOEFL exam offers mainly academic texts, IELTS is available in two modules - Academic Training (academic course) and General Training (general language training course) they contain scientific and general texts, respectively. The CAE exam offers a wide selection of texts on various topics of a pragmatic orientation (Aravind \& Rajasekaran, 2020; Coccetta, 2018; Putnam et al., 2016). Apart from this, all the tests contain a different number of tasks. The TOEFL includes 3 texts and 36 questions, the IELTS has 3 texts and 40 questions, whereas the $\mathrm{CAE}(\mathrm{C} 1)$ has a more original structure, in which tasks for checking reading skills are interspersed with those on grammar, word formation, and vocabulary. In all the tests, reading tasks differ in volume and context used. Thus, in addition to the knowledge of grammar and vocabulary, over the exam, students must demonstrate good skimming skills as they declare a good reading comprehension ability and allow predicting the plot of the text (Allen, 2020; Allen et al., 2016).

The analysis of scientific sources on the topic has revealed that most studies describe IELTS, CAE, and TOEFL only in general terms. Among other things, an in-depth analysis of their Reading sections and the practice of using language proficiency tests in Russian higher educational institutions are outlined insufficiently. For these particular reasons, the present work aims to describe the procedure for assessing reading skills using the results of Russian students enrolled in international language exams CAE (C1), TOEFL, and IELTS. According to the goal set, the following research tasks were formulated:

1. Analyze the Reading sections of IELTS, CAE, and TOEFL exams, and determine what reading skills should be developed for good results.

2. Evaluate the progress of students in passing IELTS, CAE, and TOEFL tests.

3. Assess students' reading comprehension skills for different types of reading.

4. Develop recommendations for the successful passing of a language proficiency test.

\section{Research object and subject}

The object of analysis and assessment is represented by students' online reading skills, whereas the subject is their formation level.

\section{METHOD}

\section{Data Analysis}

The method used to identify the level of respondents' reading skills is an exam in the test form, in which the test materials prove to function as the main evaluating medium. In order to analyze the results obtained, the study applied the method of descriptive cross-sectional statistical analysis. Data visualization was carried out by means of the Microsoft Excel spreadsheet. 


\section{Research Participants}

The study involved 662 second-year students of all faculties of the National Research University "Higher School of Economics" (HSE), Nizhny Novgorod Campus, Russia. Students participating in the exam had different levels of language competence and experience. Their language proficiency levels varied from B1 to $\mathrm{C} 1+$. All respondents were distributed into groups and then in subgroups, ranging in size from eight to twelve people. This was done to create a more comfortable psychological atmosphere. The research data cover the period from 2013 to 2015. More detailed information concerning the research participants is presented in Table 1.

Table 1

Research sample distribution

\begin{tabular}{llllll}
\hline Years & $\begin{array}{l}\text { The total number of } \\
\text { HSE students } \\
\text { studying English }\end{array}$ & $\begin{array}{l}\text { The number of } \\
\text { exam participants }\end{array}$ & TOEFL & $\begin{array}{l}\text { CAE } \\
\text { (C1) }\end{array}$ & $\begin{array}{l}\text { IELTS } \\
\text { (Academic } \\
\text { Training) }\end{array}$ \\
\hline 2013 & $456(100 \%)$ & $111(24 \%)$ & 36 & 29 & 66 \\
\hline 2014 & $521(100 \%)$ & $224(43 \%)$ & 31 & 42 & 151 \\
\hline 2015 & $598(100 \%)$ & $287(48 \%)$ & 24 & 52 & 211 \\
\hline
\end{tabular}

\section{Research Limitations}

This research has several limitations. The first is that the sample was confined to only one university and students of the second year of study. The second limitation lies in the fact that the paper did not take into account any differences in gender, age, or respondents' social status. What is more, the study focused largely on the Reading section - only one type of all examination tasks. In view of this, future research should consider all the noted aspects to achieve more comprehensive results.

\section{Testing Procedure}

In 2013, an experimental test was organized at the HSE, in which the first 111 people took part. This before-exam testing was of the diagnostic character. It had a purpose to familiarize students with the format of International English Examinations and assess their readiness for passing them. This step was necessary since all the previous university English exams were arranged in a traditional form, being different from international testing.

At the stage of preparation for testing, students were told about each exam type and the kinds of exam exercises in general and in particular. Apart from this, respondents were demonstrated strategies of how to do different assignments. Next meeting sessions were devoted to the requirements and rules of testing procedures. Besides, students were acquainted with the exam assessment scales.

The stage of preparation also included brainstorming: research participants were asked to perform tasks similar to those offered in the tests' Reading sections. As different types of assignments are evaluated differently depending on the test, students were informed about the "cost" of each assignment in points. For this purpose, the Classroom Assessment Techniques were used. 
In the final part of the preparatory stage, the questionnaire method was applied: students answered questions to identify their attitude towards a particular type of exam as a form of control of their language proficiency. In particular, it was necessary to establish which of the examination types were the most difficult and which factors inspired students to choose a specific exam type. These survey results were further used to adjust the policy of the Department of Foreign Languages in terms of choosing a particular international exam.

Preparation for testing students at HSE was arranged by teachers of the Department of Applied Linguistics and Foreign Languages, together with specialists from the University Language Training Center.

Intending to obtain more successfully passed tests and allow students to develop their reading skills, teachers performed preparatory work of three stages: pre-reading stage, reading stage and post-reading stage.

The pre-reading stage included the strategies "Survey!" and "Question!"

1. Strategy "Survey" - survey the text before reading!

A. The students read learning objectives and the text title.

B. The students predict the ideas of the text.

C. The students also note headings and subheadings, graphics, captions under pictures, and italics throughout the text.

D. The students overview the text and create a mental framework for understanding the text more thoroughly.

2. Strategy "Question" - ask questions while surveying!

A. The students understand questions correctly.

B. The students should be attentive to negations.

C. The students find relevancies between the title, headings, and/or subheadings and questions.

The reading stage included the strategies "Read!" and "Recite!"

3. Strategy "Read" - read very carefully!

A. The students peruse the title, the headings and the subheadings.

B. The students summarize what has just been read.

C. The students seek clarification on difficult points in the paragraph.

D. The students should reduce their reading speed for difficult paragraphs.

E. The students should stop and reread parts that are not clear.

4. Strategy "Recite"- recite the test materials!

A. The students study the topic sentence of each paragraph.

B. The students find keywords and/or word combinations.

C. The students deeply go into every sentence and/or paragraph.

D. The students should be very careful: as usual, the first sentence contains the most important thought of the whole paragraph, but not always.

E. The students answer questions focusing on the most important thought of the paragraph. 
The post-reading stage included only the strategy "Review!"

5. Strategy "Review!" - check the answers attentively!

A. The students check their answers to questions.

B. The students should make sure that the proposed tasks are interpreted correctly and compare the tasks in the test with the key ideas of the text itself.

C. Upon completion of assignments in the Reading section, it is necessary to check all the answers and make the necessary corrections (Aziz, 2019; Bae et al., 2019).

\section{Technical requirements for the testing procedure and tools used}

The main way to monitor and assess language proficiency is an international independent examination conducted in the form of testing. During the testing, the accuracy and completeness of the text understanding are evaluated while taking into account the time parameter. Students fulfill particular tasks, which are presented in the open or closed form. The open testing form is supposed to involve tasks to complete the text with the necessary information and obtain the correct answer. The closed form means that the English language learner has to choose the true answer from a row of items, with only one correct while the others are not.

The testing procedure supposed no physical participation of English teachers in the test preparation and the examination. Test materials were provided by Certified Centers for the arrangement of international examinations and were given to students individually by specially trained managers on the testing date. The examination procedure was monitored by the representatives of the Educational Department and Deans' offices of HSE.

Each type of exam assumed a balanced structure in which all types of language competencies were tested. The data on the duration of the test, its volume, structure, and content are presented in Table 2.

Table 2

Overview of the Reading section tasks across three tests

\begin{tabular}{lllll}
\hline \multirow{2}{*}{ Criteria } & TOEFL & IELTS & Academic \\
\cline { 3 - 5 } & Training & $\begin{array}{l}\text { General } \\
\text { Training }\end{array}$ & CAE (C1) \\
\hline Duration & $60-80$ minutes & 60 minutes & 60 minutes & $\begin{array}{l}\text { 90 minutes (reading + } \\
\text { use of English) }\end{array}$ \\
\hline $\begin{array}{l}\text { Number of } \\
\text { tasks }\end{array}$ & $\begin{array}{l}\text { 3-4 texts (12-14 } \\
\text { questions each), }\end{array}$ & $\begin{array}{l}3 \text { texts, 40 } \\
\text { questions total }\end{array}$ & $\begin{array}{l}3 \text { texts, 40 } \\
\text { questions total (2-3 } \\
\text { short texts, 1 long } \\
\text { text) }\end{array}$ & $\begin{array}{l}8 \text { parts, 56 questions } \\
\text { total }\end{array}$ \\
\hline Types of tasks & $\begin{array}{l}\text { academic texts, } \\
\text { news sources }\end{array}$ & $\begin{array}{l}\text { non-fiction, } \\
\text { newspaper and } \\
\text { journal articles }\end{array}$ & $\begin{array}{l}\text { advertisement, } \\
\text { tabloid and } \\
\text { magazine articles }\end{array}$ & $\begin{array}{l}\text { fiction and non-fiction } \\
\text { books, newspaper and } \\
\text { magazine articles }\end{array}$ \\
\hline $\begin{array}{l}\text { Length of } \\
\text { passage }\end{array}$ & max. 700 words & max. 3000 words & $\begin{array}{l}\text { max. 1500-2500 } \\
\text { words }\end{array}$ & max. 3500 words \\
\hline
\end{tabular}


The time for completing tasks in the Reading section varied from 60 minutes (IELTS exam) to 80 minutes (TOEFL exam) and even up to an hour and a half if the test tasks were performed in the CAE (C1) format.

Reading presupposes active student activity and different goals of such activity, in particular, understanding and correct interpretation of the text (Blachowicz \& Ogle, 2017; McNamara, 2017; van der Linden, 2018; Zumbo \& Hubley, 2016). Table 3 below proposes matching of the reading types and testing items.

Table 3

Test tasks in their correlation with reading skills

\begin{tabular}{|c|c|c|}
\hline $\begin{array}{l}\text { Reading } \\
\text { types }\end{array}$ & Reading skills to be checked & Test exercises \\
\hline \multirow{10}{*}{$\begin{array}{l}\text { Scan- } \\
\text { reading }\end{array}$} & understand explicit information in the text & multiple choice \\
\hline & identify the main idea & true/false/not given \\
\hline & separate the basic facts from the unimportant & information transfer \\
\hline & $\begin{array}{l}\text { set explicitly expressed logical and causal relationships } \\
\text { between facts }\end{array}$ & $\begin{array}{l}\text { (multiple) matching } \\
\text { free recall }\end{array}$ \\
\hline & distinguish opinion from fact & true/false/not given \\
\hline & define the communicative task of the text & free recall \\
\hline & draw conclusions & short answer \\
\hline & $\begin{array}{l}\text { predict possible developments on the basis of textual } \\
\text { information }\end{array}$ & (multiple) matching \\
\hline & $\begin{array}{l}\text { understand unfamiliar words using a language guess based } \\
\text { on (a) knowledge of word formation methods, (b) context }\end{array}$ & $\begin{array}{l}\text { cloze } \\
\text { multiple choice }\end{array}$ \\
\hline & $\begin{array}{l}\text { Identify and determine the means of local connectivity } \\
\text { (reference, substitution, lexical cohesion, etc.) }\end{array}$ & gap filling \\
\hline \multirow[t]{3}{*}{$\begin{array}{l}\text { Skim- } \\
\text { reading }\end{array}$} & $\begin{array}{l}\text { understand the main content of the text, highlight the main } \\
\text { facts/main line of evidence, the author's arguments }\end{array}$ & $\begin{array}{l}\text { multiple choice } \\
\text { true/false/not given (multiple) } \\
\text { matching } \\
\text { (gapped) summary }\end{array}$ \\
\hline & $\begin{array}{l}\text { analyze the composition of the text, highlight its semantic } \\
\text { parts (beginning, main part, conclusion) }\end{array}$ & $\begin{array}{l}\text { matching } \\
\text { sequencing }\end{array}$ \\
\hline & highlight the syntactic structure (at the macro level) & sequencing \\
\hline \multirow[t]{4}{*}{$\begin{array}{l}\text { In-depth } \\
\text { reading }\end{array}$} & find out the syntactic structure (at the macro level) & $\begin{array}{l}\text { information transfer } \\
\text { sequencing }\end{array}$ \\
\hline & $\begin{array}{l}\text { determine the topic, subtopic text based on the } \\
\text { title/subheadings/illustrations/number }\end{array}$ & information transfer \\
\hline & complete sentences based on the content of the text & sentence completion \\
\hline & $\begin{array}{l}\text { search and find the information needed, such as the } \\
\text { definition, wording, numbers, etc. }\end{array}$ & $\begin{array}{l}\text { multiple choice } \\
\text { sequencing } \\
\text { short answer/sentence } \\
\text { completion information transfer } \\
\text { (e.g., flow chart) }\end{array}$ \\
\hline
\end{tabular}

\section{Students' Progress Assessment}

The main difference in estimating students' progress by passing the exam in the traditional form and doing tasks in the test form is that the latter always includes measuring the results by means of a matrix (special scale). The correlation between the 
HSE's rating scale for international exams and the traditional 5-point scale of the Russian education system clearly demonstrates the advantages and disadvantages of different format score scales (see Table 4).

Table 4

Correlation of result assessment scales

\begin{tabular}{llllll}
\hline $\begin{array}{l}\text { HSE Internal } \\
\text { Assessment } \\
\text { Scale }\end{array}$ & $\begin{array}{l}\text { HSE Internal } \\
\text { International Exam } \\
(\%)\end{array}$ & $\begin{array}{l}\text { Rating } \\
\text { Scale for } \\
\text { TOEFL }\end{array}$ & $\begin{array}{l}\text { Rating } \\
\text { Scale for } \\
\text { IELTS }\end{array}$ & $\begin{array}{l}\text { Rating } \\
\text { Scale for } \\
\text { CAE (C1) }\end{array}$ & $\begin{array}{l}\text { Traditional } \\
\text { 5-point Scale }\end{array}$ \\
\hline 10 & $90-100$ & $110-120$ & $8-9$ & Grade A & excellent \\
\hline 9 & $80-89$ & $102-109$ & 7.5 & Grade B & excellent \\
\hline 8 & $70-79$ & $94-101$ & 7 & Grade C & excellent \\
\hline 7 & $60-69$ & $79-93$ & 6.5 & & good \\
\hline 5 & $50-59$ & $60-78$ & 6 & good \\
\hline 4 & $40-49$ & $46-59$ & 5.5 & satisfactory \\
\hline 3 & $30-39$ & $35-45$ & 5 & satisfactory \\
\hline
\end{tabular}

In contrast to the traditional 5-point scale in Russia, the assessment systems applied in international tests allow determining the level of foreign language competence formation both individually and in comparison with others. The accuracy of such assessment is higher because international examinations use a more fractional scale, which allows one to correlate a greater number of scores with a larger number of parameters and assessment criteria.

\section{FINDINGS}

The reading tasks proposed in all three tests relate to the three reading techniques, presented in Figure 1.

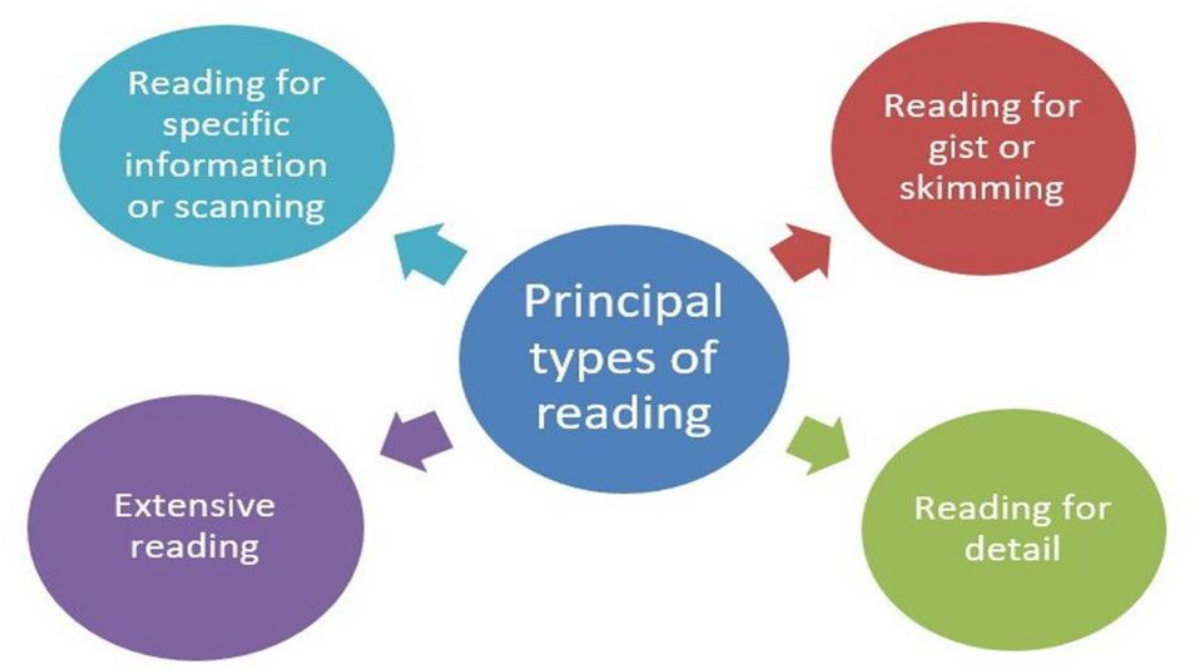

Figure 1

Principal types of reading techniques 


\section{Reading for specific information or scanning (Scan-reading)}

A type of reading that involves understanding the content of the text as a whole. The student must have the skills of outlining individual elements, detecting logical connections, searching for semantic connections between the parts of the text, finding keywords, highlighting the primary information.

\section{Reading for gist or skimming (Skim-reading)}

A type of reading that involves not only obtaining the basic information from the text but also predicting its main idea. The student is to be able to identify semantic and structural connections within the text and understand its chronological and logical structure. To pass the test, one should know the prediction elements at the semantic level. The reader should anticipate the possible continuation and completion of each segment of the text, find connections between the described events and facts, etc.

\section{Reading for detail (In-depth reading)}

This type of reading presupposes the complete receipt of information from the text and understanding of its details both at the content and deep structure level. Since the tests include tasks on understanding specific details and unique features of the text, the student must be able to separate subjective and objective information, determine information by context, use text clues in the form of headings, keywords, and the like elements. Understanding requires identifying chronological or logical connections as one reads.

Analysis of the Reading section tasks across language proficiency tests of different formats revealed numerous differences in the formation of reading skills. What is common for the considered tests is the content of several answer options and the texts' authenticity. Aiming to check the first two reading skills (scanning and skimming), they use material retrieved from journals, advertising, announcements, information brochures or guidebooks. In contrast, in-depth reading is checked with the help of fragments retrieved from fiction, analytical newspapers, magazine articles, and popular scientific texts of high complexity.

The examination of test materials with reference to their structure and content showed that tests on different reading types include approximately an equal number of tasks. However, the shared trend for all international exams can be defined as an increase in reading-for-detail tasks as they require the student's competence to interpret the text on the whole (see Figure 2). 


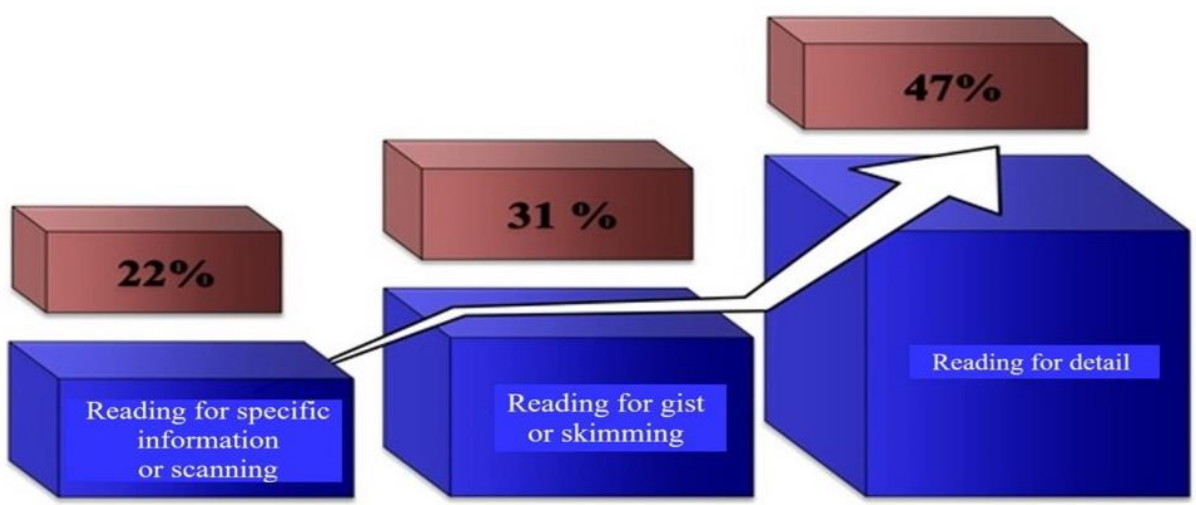

Figure 2

Reading tasks tendencies in language proficiency tests

In all three tests under consideration (IELTS, TOEFL, CAE), the Reading section aims to test students for mastery of different reading techniques. Reading for specific information or scanning requires the performance of such tasks as multiple choice and multiple matching. Reading for gist and skimming is focused on matching headings with the parts of the text and gapped wordings. From the point of view of cognitive activity, this is the most common operation when operating with online texts (Aravind \& Rajasekaran, 2020). Reading for detail, in turn, offers such tasks as sequencing, understanding and extracting the semantic structure of the text, Use of English. The Use of English task is only performed when passing the exam in the TOEFL and the CAE formats.

As of the examination results, $3.6 \%$ of students from a total of 111 involved failed to complete their reading assignments in 2013. In 2014, the total number of students taking the international exam as well as those who met no success with reading tasks increased to 224 individuals and $6 \%$, respectively. However, despite the one more increase in the number of participants to 287 the following year, only $5.5 \%$ failed the Reading part. Table 5 shows the number of students who did not pass the Reading by the exam format.

Table 5

Number of students not succeeded in reading

\begin{tabular}{llllll}
\hline Years & $\begin{array}{l}\text { The total number of } \\
\text { students passing }\end{array}$ & $\begin{array}{l}\text { Percentage of those } \\
\text { failed }\end{array}$ & TOEFL & $\begin{array}{l}\text { CAE } \\
\text { (C1) }\end{array}$ & $\begin{array}{l}\text { IELTS } \\
\text { (Academic Training) }\end{array}$ \\
\hline 2013 & 111 & $3.6 \%$ & $1 \%$ & $2 \%$ & $0.6 \%$ \\
\hline 2014 & 224 & $6 \%$ & $2 \%$ & $3 \%$ & $1 \%$ \\
\hline 2015 & 287 & $2.8 \%$ & $1 \%$ & $1 \%$ & $0.8 \%$ \\
\hline Total & 622 & $3.4 \%$ & $1 \%$ & $2 \%$ & $0.4 \%$ \\
\hline
\end{tabular}

As follows from Table 5, the CAE was the most difficult exam for second-years. This suggests a higher level of difficulty of the CAE tasks, as they embrace all reading types and include grammar and vocabulary exercises. The table also illustrates a new trend - 
first, the CAE tasks proved to be complicated for students, but in 2015 the situation changed, and the number of students who did not pass the IELTS and CAE exams amounted to the same quantity -7 . The reason for this is that the IELTS developers have resorted to complicating tasks by including authentic passages from scientific articles and other sources of increased difficulty in the Reading section. Experience with examinations shows that deep comprehension tests always give a lower average score than the other two types of reading.

Table 6 presents the total number of exam participants (622) who passed international exams over the period of 2013-2015.

Table 6

Results for different types of reading

\begin{tabular}{|c|c|c|c|}
\hline $\begin{array}{l}\text { Reading } \\
\text { type }\end{array}$ & Task kinds & Task description & $\begin{array}{l}\text { Ratio of correct } \\
\text { and all answers } \\
\mathrm{N}=622\end{array}$ \\
\hline \multirow{2}{*}{$\begin{array}{l}\text { Scan- } \\
\text { reading }\end{array}$} & Multiple Choice & to choose one of the suggested answers & $96 \%$ \\
\hline & Multiple Matching & $\begin{array}{l}\text { to read a few short articles or passages } \\
\text { related to the same topic and find a match } \\
\text { between the } \\
\text { headings/phrases/statements/questions in } \\
\text { the texts (some answer choices can be used } \\
\text { more than once) }\end{array}$ & $96 \%$ \\
\hline \multirow[t]{2}{*}{$\begin{array}{l}\text { Skim- } \\
\text { reading }\end{array}$} & $\begin{array}{l}\text { Matching headings with } \\
\text { the parts of the text }\end{array}$ & $\begin{array}{l}\text { to choose the appropriate title to the text } \\
\text { paragraphs }\end{array}$ & $96.2 \%$ \\
\hline & Gapped texts & $\begin{array}{l}\text { to insert words into the gaps or to restore } \\
\text { the logic of the text extracts }\end{array}$ & $94.5 \%$ \\
\hline \multirow[t]{3}{*}{$\begin{array}{l}\text { In-depth } \\
\text { reading }\end{array}$} & Sequencing & $\begin{array}{l}\text { to arrange paragraphs/sentences in a logical } \\
\text { sequence, taking into account the structural } \\
\text { and semantic features of the text }\end{array}$ & $94 \%$ \\
\hline & $\begin{array}{l}\text { Understanding and } \\
\text { extracting the semantic } \\
\text { structure of the text }\end{array}$ & $\begin{array}{l}\text { to perform the tasks of } 3-5 \text { questions, the } \\
\text { answers to which require deep and full } \\
\text { understanding }\end{array}$ & $94 \%$ \\
\hline & $\begin{array}{l}\text { Use of English (TOEFL \& } \\
\text { CAE only) }\end{array}$ & $\begin{array}{l}\text { to perform tasks of different types } \\
\text { (open/close, multiple choice, fill in the } \\
\text { gaps, match the words from two columns, } \\
\text { etc.), which check the understanding of the } \\
\text { fragment/phrase, etc. }\end{array}$ & $92 \% *$ \\
\hline
\end{tabular}

$\mathrm{N}=194$

The data presented above suggest that most students have mastered all three reading techniques. In more exact terms, the number of those who successfully solved the problems with multiple choice equaled 601. At the same time, $96 \%$ showed an understanding of the dependence between headings and text fragments, and $94.5 \%$ managed to fill the gaps in the text. It should be mentioned that the task type Use of English is not available in the IELTS exam format. This was the reason for the decrease in the total number of participants - from 622 to 194 (only those who took an exam in the TOEFL and CAE formats). Among them, the share of those succeeded amounted to $92 \%$. 


\section{DISCUSSION}

In this research, it was not only essential to obtain statistically significant results but also to identify the most appropriate examination form to be recommended as a final control for individuals studying English as a foreign language. The central indicator of successful test passing is the understanding of the content presented. In view of this, an online reading may serve greatly to develop corresponding skills and become a perfect tool for collecting background knowledge.

The research novelty stems from the fact that the level of online trained reading skills of second-year students was identified by means of three world-famous language proficiency tests that use internationally recognized testing methods - CAE (C1), TOEFL and IELTS.

\section{The problem of choosing the examination form}

In our opinion, there are several reasons for choosing IELTS, CAE, and TOEFL exams: (1) as evidenced by the certificates provided by many students when entering the university, these types of exams are the most popular; (2) passing the test makes it possible to get a high mark in the language without having to pass an exam; (3) the chance to be accepted into any university abroad if a student wishes to continue his/her education there. Results of the diagnostic testing showed that students had too low English level to pass a language proficiency test. Therefore, they voluntarily asked about extra English lessons. It should be pointed out that these training sessions are of usual practice in HSE till the present time. Every year more and more students of junior courses take part in international English language testing. In 2013, the number of students who participated in the exam was $24 \%$ of the total number of second-years. By 2015 , it had consistently increased to $48 \%$, covering about half of the students and indicating a growing interest in the international examination. By 2015, the number of applicants for the IELTS had more than doubled, while the number of applicants for other types of exams decreased. This later became the reason for choosing the IELTS as the main type of examination (since 2016). Specialized preparation for such exams is increasingly being conducted online, which enhances the importance of online reading. The most difficult tasks turned out to be those focused on logical and semantic connections, logical sequence of events, and a deep understanding of the text. These tasks were failed by $5 \%$ of students. However, as all the students were involved in active training directed at reading skills improvement, a comparatively high percentage of successful tests was obtained $(95 \%)$.

\section{Typology of test items in different test systems}

Within the analysis of the Reading section, the problem of the typology of test tasks in different examination formats deserves a separate discussion.

The international TOEFL exam contains tests for correct reading comprehension. Multiple choice questions dominate, though there are also tasks with filling the gaps or interpreting the text. The academic nature of texts makes it very difficult to test real competence (Syakur, 2019). 
In Academic Reading and General Reading, the IELTS exam contains three texts, each with a different communicative focus, for example, descriptive, factual, analytical, or discussion. The IELTS Reading section includes 40 questions supposing that the student is aware of the author's intentions and how the author felt about what he/she wrote.

The IELTS General Reading format usually has three texts. They contain the same types of exercises as the Academic one. Sometimes students are given up to six texts of a smaller volume with one general topic. Besides, the texts in General Reading are less complicated, and their vocabulary is easier for understanding the plot.

The Reading section of the CAE (C1) exam has eight sections and contains tasks on text comprehension, vocabulary, competence in word formation, and grammar. The difficulty is determined by the communicative significance of each individual skill, the complexity of the language material, and the topics used. The most common types of assignments are the following: multiple choice tasks, true/false statements, paraphrasing, matching. Texts are mainly general. Checking competence is mostly aimed at testing the students' skills to memorize, identify parts of speech, analyze the passage, and get logical conclusions. The exam covers preparation levels from elementary to advanced. The C1 level of CAE is designed mainly for students majoring in philology and linguistics. A comparative analysis of reading tasks in the TOEFL, IELTS, and CAE is presented in Table 7.

Table 7

Variants of reading tasks in the TOEFL/IELTS/CAE

\begin{tabular}{lllll}
\hline \multirow{2}{*}{$\begin{array}{l}\text { Types of } \\
\text { tasks }\end{array}$} & $\begin{array}{l}\text { TOEFL } \\
\text { (all tasks multiple } \\
\text { choice) }\end{array}$ & Academic & General & CAE (C1) \\
\cline { 2 - 5 } $1^{\text {st }}$ type & True/false & True/false/not given & True/false/not given & True/false/not given \\
\hline $2^{\text {nd }}$ type & $\begin{array}{l}\text { Multiple choice } \\
\text { questions }\end{array}$ & $\begin{array}{l}\text { Multiple choice } \\
\text { questions }\end{array}$ & $\begin{array}{l}\text { Multiple choice } \\
\text { questions }\end{array}$ & $\begin{array}{l}\text { Multiple choice } \\
\text { questions }\end{array}$ \\
\hline $2^{\text {nd }}$ & & $\begin{array}{l}\text { Short written } \\
\text { answers }\end{array}$ & $\begin{array}{l}\text { Short written } \\
\text { answers }\end{array}$ & \\
\hline $3^{\text {rd }}$ type & $\begin{array}{l}\text { Matching the } \\
\text { information between } \\
\text { paragraphs }\end{array}$ & $\begin{array}{l}\text { Matching } \\
\text { lists/phrases }\end{array}$ & & Cross-text multiple \\
& & $\begin{array}{l}\text { Choosing from a } \\
\text { bank of headings }\end{array}$ & $\begin{array}{l}\text { Choosing from a } \\
\text { bank of headings }\end{array}$ & \\
\hline $4^{\text {th }}$ type & & Filling in the gaps & Filling in the gaps & $\begin{array}{l}\text { Open/close (find the } \\
\text { correct word for } \\
\text { every gap) }\end{array}$ \\
\hline $5^{\text {th } \text { type }}$ & Filling in the gaps & & & \\
\hline $6^{\text {th }}$ type & & $\begin{array}{l}\text { Summary/diagram } \\
\text { /label completion }\end{array}$ & $\begin{array}{l}\text { Summary/diagram } \\
\text { /label completion }\end{array}$ & \\
\hline $7^{\text {th }}$ type & Use of English & & & Use of English \\
\hline
\end{tabular}

In addition to reading skills, CAE (C1) and TOEFL test a number of other competencies, like the formation of grammatical skills, vocabulary, and word formation (Use of English). IELTS, in contrast, does not consider these aspects. The distinctions also relate to the time parameters - the least amount of time $(60 \mathrm{~min})$ is given in the structure of the IELTS exam to complete the tasks in the Reading section. 


\section{CONCLUSIONS}

Language proficiency testing is proved to be a cost-effective, objective, and suitable way to measure students' achievements. The diagnostic and statistical analysis of several international English testing methodologies allowed comparing and differentiating skills needed for different examinations. This may assist in developing particular traits of character, such as persistence in achieving learning goals, perseverance, flexibility, and creative thinking. The distinct advantage of such testing is its focus on the use of modern information technologies. The quantitative coverage of online training material, successful development of students' skills, creative application of e-learning strategies, variety of techniques and methods of teaching students are essential for collaborative work, effective development of online reading skills, and successful language test passing.

The analysis of the TOEFL, IELTS, and CAE testing methodologies made it possible to distinguish three principal reading techniques necessary for passing the exam:

1. Scan-reading.

2. Skim-reading.

3. In-depth reading.

As follows from the study findings, most students enrolled passed the exams successfully, performing best in scan-reading tasks (96\%). The share of unsuccessful attempts ranged from $3.6 \%$ (2013) to $3 \%$ (2015). The testing proposed by the CAE was defined as the most difficult due to the higher complexity of its tasks, embracing three reading techniques as well as grammar and vocabulary exercises. However, as comes from the examination outcomes, $95 \%$ of students have successfully mastered reading skills while passing the international TOEFL, IELTS, CAE exams.

Given the results of language proficiency testing among HSE students, one can infer that highly qualified online preparation is the best way to cope with English knowledge tasks. It is equally important in the form of individual work and teacher guidance. The additional classes and online consultation hours for English learners, as well as participation in different language competitions, can assist significantly in attempts to achieve progress.

\section{RECOMMENDATIONS}

To pass any language exam on a first try, students require a deep immersion in a foreign language environment. The most natural way to achieve this deep immersion is elearning and communication with native speakers abroad. In general, to take any of the reviewed tests successfully, the following major recommendations can be made:

- Carefully read the rules of the exam procedure before taking an exam.

- Have a good English proficiency level.

- Use suitable reading strategies.

- Get acquainted with the criteria of assessment attentively. 
For best results in the Reading section, one should use a strategy related to the pattern of decisions for collecting and using information (Tawfiq, 2019). These strategies are related to the types (modes) of reading and the degree of development of the material being read.

\section{Strategies for scan-reading tasks}

It is recommended to read the opening and closing paragraphs of the text fragment more carefully to understand the information in general. Special attention is paid to headings, italics, captions for illustrations and other key elements of the text. The student should not scatter attention and waste the exam time on unfamiliar words because the test does not expect a complete understanding of the entire volume of the text. One should understand the meaning of words from the context or even ignore some of them.

\section{Strategies for skim-reading tasks}

This type of reading requires the competence to purposefully extract the necessary information, that is, to use a selective strategy. The model developed by Yang based on interactive reading theory makes it possible to increase the adaptability of this process and proposes other effective methods for analyzing text during reading and anticipating its content (Yang, 2018). Skim-reading requires foreseeing the grammar structure of the sentences tested to fill in the gaps correctly. In other words, to make an appropriate choice between parts of the sentence/words from the options given. Many researchers point to the effectiveness of special mnemonic methods such as mind-map for a deeper understanding and reliable memorization of vocabulary (Astriani et al., 2020).

\section{Strategies for in-depth reading tasks}

The test of this level requires knowledge of strategies for recognizing the key information. Along with the approach mentioned above, the correct selection of grammatical material is to be applied. It involves, for example, the examinee's competence to predict the content and interpret negative constructions, as they can change the entire meaning to the opposite. Search performance depends on comprehension skills, which must be practiced both while learning the language and on one's own (Tourimpampa et al., 2018). Paying attention to the tenses helps find respective correspondence between the text vocabulary and the time described.

Regardless of the type of reading, successful completion of the examination tasks not only helps the student to develop a wide range of competencies but also enables a proper organization of work over the exam, with reference to the basic principles of time management.

\section{REFERENCES}

Adesope, O. O., Trevisan, D. A., \& Sundararajan, N. (2017). Rethinking the use of tests: A meta-analysis of practice testing. Review of Educational Research, 87(3), 659-701.

Allen, L. K., Jacovina, M. E., \& McNamara, D. S. (2016). Cohesive Features of Deep Text Comprehension Processes. In Proceedings of the $38^{\text {th }}$ Annual Meeting of the 
Cognitive Science Society in Philadelphia, PA. Cognitive Science Society (pp. 26812686). Austin, TX: Published with acknowledgment of federal support.

Allen, V. (2020). Strategies for understanding and supporting primary school children. In Supporting Behavioural, Emotional and Social Difficulties in School (pp. 37-40). London: Routledge.

Aravind, B. R., \& Rajasekaran, V. (2020). A descriptive study on ESL learners' vocabulary knowledge through cognitive and metacognitive strategies. English Language Teaching Educational Journal, 3(2), 142-150.

Astriani, D., Susilo, H., Suwono, H., Lukiati, B., \& Purnomo, A. (2020). Mind Mapping in Learning Models: A Tool to Improve Student Metacognitive Skills. International Journal of Emerging Technologies in Learning, 15(6), 4-17.

Axmatilloyevna, I. N., Bahodirovna, T. T., Norbayevna, K. E., Zokirovna, S. Z., \& Botirovna, S. Z. (2020). Testing as a learning knowledge control method in foreign language teaching process. ACADEMICIA: An International Multidisciplinary Research Journal, 10(5), 1024-1029.

Aziz, I. N. (2019). Implementation of SQ3R Method in Improving the Students' Basic Reading Skill. EDUCATIO: Journal of Education, 4(1), 102-110.

Aziz, M. N. A., \& Yusoff, N. M. (2018). Experiences of using Authentic Assessment with English Language Young Learners. International Journal of Academic Research in Business and Social Sciences, 8(9), 375-738.

Bae, C. L., Therriault, D. J., \& Redifer, J. L. (2019). Investigating the testing effect: Retrieval as a characteristic of effective study strategies. Learning and Instruction, 60, 206-214.

Bandalos, D. L. (2018). Measurement theory and applications for the social sciences. New York, London: Guilford Publications.

Bilikozen, N., \& Akyel, A. (2014). EFL reading comprehension, individual differences and text difficulty. Reading, 14(2), 263-296.

Blachowicz, C., \& Ogle, D. (2017). Reading comprehension: Strategies for independent learners. New York, NY: Guilford Publications.

Black, M. (2018). Critical thinking: An introduction to logic and scientific method. Auckland: Pickle Partners Publishing.

Briz-Ponce, L., Pereira, A., Carvalho, L., Juanes-Méndez, J. A., \& García-Peñalvo, F. J. (2017). Learning with mobile technologies-Students' behavior. Computers in Human Behavior, 72, 612-620.

Cho, K. S., \& Krashen, S. (2019). Pleasure reading in a foreign language and competence in speaking, listening, reading and writing. TEFLIN Journal, 30(2), 231236. 
Coccetta, F. (2018). Developing university students' multimodal communicative competence: Field research into multimodal text studies in English. System, 77, 19-27.

Craven, L. (2017). Measuring language performance: complexity, accuracy and fluency measures. In The 2017 WEI International Academic Conference Proceedings (pp. 2527).

Delfi, S., Jismulatif, J., \& Diah, F. S. (2020). Personal Reading Histories for Personal Reading Interest. Journal of Educational Sciences, 4(3), 694-704.

Demitriadou, E., Stavroulia, K. E., \& Lanitis, A. (2020). Comparative evaluation of virtual and augmented reality for teaching mathematics in primary education. Education and Information Technologies, 25(1), 381-401.

Fojtik, R. (2014). Mobile Technologies Education. Procedia - Social and Behavioral Sciences, 143, 342-346.

Giraldo, F. (2018). Language assessment literacy: Implications for language teachers. Profile Issues in Teachers Professional Development, 20(1), 179-195.

Grabe, W., \& Jiang, X. (2018). First language and second language reading. In The TESOL Encyclopedia of English Language Teaching (pp. 1-7). Hoboken, NJ: John Wiley \& Sons, Inc.

Grabe, W., \& Stoller, F. L. (2019). Teaching and researching reading. London: Routledge.

Hedgcock, J. S., \& Ferris, D. R. (2018). Teaching readers of English: Students, texts, and contexts. London: Routledge.

Hooshyar, D., Pedaste, M., Saks, K., Leijen, Ä., Bardone, E., \& Wang, M. (2020). Open learner models in supporting self-regulated learning in higher education: A systematic literature review. Computers \& Education, 154, 103878.

Hura, S. L. (2017). Usability testing of spoken conversational systems. Journal of Usability Studies, 12(4), 155-163.

Ihata, A. C., \& Ihata, T. (2017). Reading in English as a foreign language: Relative contributions of vocabulary and phonological awareness. PEOPLE: International Journal of Social Sciences, 3(3), 694-711.

Kameneva, G. A., Romanov, P. Y., Anisimov, A. L., \& Bondarenko, T. A. (2018). Using Test Technologies in the Conditions of Informatization of Higher Education. In 7th icCSBs 2018 The Annual International Conference on Cognitive-Social, and Behavioural Sciences (pp. 670-677). Future Academy.

Matsuda, A. (2017). Preparing teachers to teach English as an international language. Bristol, Blue Ridge Summit, PA: Multilingual Matters. 
McNamara, D. S. (2017). Self-explanation and reading strategy training (SERT) improves low-knowledge students' science course performance. Discourse Processes, 54(7), 479-492.

McNamara, D. S., Ozuru, Y., \& Floyd, R. G. (2017). Comprehension challenges in the fourth grade: The roles of text cohesion, text genre, and readers' prior knowledge. International electronic journal of elementary education, 4(1), 229-257.

Pachler, N., Cook, J., \& Bachmair, B. (2010). Appropriation of Mobile Cultural Resources for Learning. International Journal of Mobile and Blended Learning, 2(1), $1-21$.

Player-Koro, C. (2019). 13. Digitization of Schools and Education. In U. Carlsson (Ed.), Understanding Media and Information Literacy (MIL) in the Digital Age (pp. 127-152). Göteborg: University of Gothenburg.

Pollock, L. (2018). Concepts and concreteness in psycholinguistics (Doctoral dissertation). London: University College London.

Purpura, J. E., \& Christison, M. (2016). A Lifetime of Language Testing: An Interview with Adrian (Buzz) Palmer. Language Assessment Quarterly, 13(2), 142-155.

Putnam, A. L., Sungkhasettee, V. W., \& Roediger III, H. L. (2016). Optimizing learning in college: tips from cognitive psychology. Perspectives on Psychological Science, $11(5), 652-660$.

Rahman, M. S. (2017). The Advantages and Disadvantages of Using Qualitative and Quantitative Approaches and Methods in Language" Testing and Assessment" Research: A Literature Review. Journal of Education and Learning, 6(1), 102-112.

Seok, S., \& DaCosta, B. (2017). Achieving Reading Competency: Factors That Influence Perceptions and Behaviors With Regard to Digital vs. Print Text. In Society for Information Technology \& Teacher Education International Conference. Association for the Advancement of Computing in Education (AACE) (pp. 1414-1419).

Shohamy, E., Or, I. G., \& May, S. (2017). Language testing and assessment. Cham: Springer.

Susanto, R., Rachmadtullah, R., \& Rachbini, W. (2020). Technological and Pedagogical Models: Analysis of Factors and Measurement of Learning Outcomes in Education. Journal of Ethnic and Cultural Studies, 7(2), 1-14.

Syakur, A. (2019). Application of E-Learning as a Method in Educational Model to Increase the TOEFL Score in Higher Education. Journal of Development Research, 3(2), 111-116.

Tawfiq, B. M. (2019). Study in thinking (skill, characteristics, types). Nasaq, 6(23), 104-134.

Tkachenko, E. S., \& Bredikhina, I. A. (2019). Linguodidactic testing, as a means of controlling the formation of the communicative competence of students of language 
training courses. In Language in the field of professional communication (pp. 214-218). Yekarenburg: Publishing house "Azhur".

Tourimpampa, A., Drigas, A., Economou, A., \& Roussos, P. (2018). Perception and Text Comprehension. It's a Matter of Perception! International Journal of Emerging Technologies in Learning, 13(7), 228-242.

Ulker, U. (2019). Reading Activities in Blended Learning: Recommendations for University Language Preparatory Course Teachers. International Journal of Social Sciences \& Educational Studies, 5(3), 83-94.

Urmston, A., Raquel, M., \& Aryadoust, V. (2016). Can Diagnosing University Students' English Proficiency Facilitate Language Development?. In J. Read (Ed.), Postadmission Language Assessment of University Students (pp. 87-109). Cham: Springer.

van der Linden, W. J. (2018). Optimal test design. In Handbook of item response theory: Vol. 3. Applications (pp. 167-195). Berlin: Springer Science \& Business Media.

Weideman, A. (2019). Degrees of adequacy: the disclosure of levels of validity in language assessment. Koers, 84(1), 1-15.

Wibowo, Y., Syafrizal, S., \& Syafryadin, S. (2020). An Analysis of English Teachers' Strategies in Teaching Reading Comprehension. Journal of Applied Linguistics and Literacy, 4(1), 20-27.

Yang, J. (2013). Mobile Assisted Language Learning: Review of the Recent Applications of Emerging Mobile Technologies. English Language Teaching, 6(7), 1925.

Yang, Y. (2018). An English Translation Teaching Model Based on Interactive Reading Theory. International Journal of Emerging Technologies in Learning, 13(8), 146-158.

Zhang, X. (2016). How does Washback of PRETCO Influence College English Teaching. In 4th International Conference on Management Science, Education Technology, Arts, Social Science and Economics 2016 (pp. 1655-1659). Amsterdam, Paris, Beijing, Zhengzhou, Hong Kong: Atlantis Press.

Zubkov, A. D. (2020). Professional Foreign Language Competence of Technical Students: Content, Structure and Formation. In Z. Anikina (Ed.), Proceedings of the Conference "Integrating Engineering Education and Humanities for Global Intercultural Perspectives" (pp. 503-510). Cham: Springer.

Zumbo, B. D., \& Hubley, A. M. (2016). Bringing consequences and side effects of testing and assessment to the foreground. Assessment in Education: Principles, Policy \& Practice, 23(2), 299-303. 